\title{
Penerimaan Diri Pada Remaja Panti Asuhan Puteri Aisyiyah Medan
}

\author{
Patrick Funaidi, Airin, Angel, Angela, Sri Hartini \\ Universitas Prima Indonesia \\ Email: Patrickfunaidi@gmail.com, airingwe@gmail.com, chocolatteparis@gmail.com, angela.ye@yahoo.com, \\ Srihartini_psikologi@unprimdn.co.id
}

\begin{abstract}
The purpose of this research is to see a picture of self-acceptance in adolescent orphanages. The source of this research consisted of five research subjects who were young women at Puteri Aisyiyah Medan Orphanage and three informants. The procedure for taking the subject uses purposive sampling technique. The research data were collected using observation and interview methods. The results obtained are that young women at Puteri Aisyiyah Orphanage have a good self-acceptance picture, and can accept themselves with their status as children of an orphanage.
\end{abstract}

Keyword : self-acceptance, orphan, teenage girl

\section{Abstrak}

Tujuan dilakukannya penelitian ini adalah untuk melihat gambaran penerimaan diri pada remaja panti asuhan. Sumber penelitian ini terdiri dari lima orang subjek penelitian yang merupakan remaja putri Panti Asuhan Puteri Aisyiyah Medan dan tiga orang informan. Prosedur pengambilan subjek menggunakan teknik purposive sampling. Data penelitian dilakukan dengan menggunakan metode observasi dan wawancara. Hasil penelitian yang diperoleh adalah remaja putri pada Panti Asuhan Puteri Aisyiyah memiliki gambaran penerimaan diri yang baik, dan dapat menerima dirinya dengan statusnya yang sebagai anak panti asuhan.

Kata kunci : penerimaan diri, anak panti, remaja putri

\section{Pendahuluan}

Keluarga merupakan objek yang paling melekat dan dekat pada anak. Dasar dari pembentukan kepribadian dan tempat manusia mengawali kehidupannya disebut sebagai keluarga. (Suprajitno, 2004) Keluarga adalah gabungan yang terdiri dari dua orang atau lebih yang di mana setiap individu hidup bersama dengan memiliki aturan, emosional dan bagian dari keluarga tersebut mempunyai peran masing-masing [13]. Keluarga terbentuk dikarenakan adanya perkawinan atau adopsi yang di mana terbentuk suatu kelompok yang terjadi interaksi dan saling menerima satu sama lain (Sahlan, 2018) [10]. Namun tidak semua anak tinggal bersama kedua orangtuanya. Hal tersebut terjadi dikarenakan beberapa hal, diantaranya ayah dan ibu yang meninggal, dititipkan orangtua, ataupun ditelantarkan oleh orangtua. Anak-anak yang seperti ini biasanya dititipkan di panti asuhan.

Anak-anak yang tidak tinggal bersama orang tua ataupun yang tidak memiliki keluarga dan di tempatkan pada sebuah lembaga untuk dijadikan tempat mendidik dikenal sebagai panti asuhan (Santoso, 2005) [11]. Di panti asuhan anak tersebut diberikan bimbingan, pendidikan dan pengawasan moral oleh pengasuh panti asuhan untuk mengisi peran orang tua yang tidak ada dengan harapan kelak tumbuh menjadi orang yang berguna dan dapat memberikan contoh yang baik di kemudian hari.

Terdapat kurang lebih tiga ratus lima belas ribu anak yang dijaga dan dibawah pengasuhan panti asuhan. Total keseluruhan panti asuhan di Indonesia yang terdaftar di Kementrian Sosial terdapat sebanyak 5.540 lokasi (www.koranjakarta.com) (Varia, 2018) [15]. Sedangkan Kementrian sosial terdata keseluruhan panti asuhan di Indonesia mencapai 5.824, dan yang terakreditasi sebanyak 1.615 panti asuhan (www.harnas.com) (Alvin Tamba, 2018) [1]. Waktu transisi dari masa anak-anak menuju dewasa disebut sebagai masa remaja. Masa remaja menjadi periode kehidupan yang penuh dinamik. Penelitian yang pernah dilakukan oleh Resty (2016) mengenai "Pengaruh Penerimaan Diri Terhadap Harga Diri Remaja di Panti Asuhan Yatim Putri Aisyiyah Yogyakarta" menyatakan bahwa penerimaan diri remaja di Panti Asuhan Yatim Piatu Aisyiyah Yogyakarta berada pada kategori cukup atau sedang [9].

Diterima Redaksi: 20-05-2020 | Selesai Revisi: 14-01-2021 | Diterbitkan Online: 16-01-2021 
Bernard (2013) menyatakan beberapa aspek dari penerimaan diri yakni memiliki kesadaran diri dan saling menghargai, berpikir positif, mampu mengembangkan potensi-potensi diri, dapat menerima diri ketika mengalami kegagalan atau mendapatkan kritikan dan tidak menilai dirinya negatif dan memiliki motivasi untuk mengubah diri [3].

Chaplin (2011) suatu perilaku individu yang didasari perasaan puas dengan kemampuan, bakat serta mengakui akan keterbatasan yang ada pada individu tersebut disebut sebagai penerimaan diri [4]. (Sutadipura, 2012) penerimaan diri lebih pada bagian yang lebih dalam dapat memberikan penjelasan mengapa yang bersangkutan berbuat dengan harus menerima hidup dengan segala kelebihan dan kekurangannya [14].

Penerimaan diri diartikan juga sebagai segala karakteristik, tingkat kemampuan dan kemauan individu untuk hidupdalam dirinya (Hurlock, 1996) [7]. Seseorang yang bisa menerima dirimereka dapat dikatakan sebagai orang yang baik-baik saja, di mana tidak mempunyai permasalahan terhadap diri sendiri sehingga individu tersebut mampu beradaptasi dengan lingkungannya.Seseorang yang mampu menerima dirinya untuk dapat memiliki pandangan positif agar lebih mengetahui dan memahami identitas dirinya yang sebenarnya, dan individu tersebut harus mengembangkannya sendiri dikarenakan tidak bisa timbul dengan sendirinya, melainkan harus dikembangkan oleh individu.

Cronbach (1963) turut menyatakan bahwa dalam menjalani kehidupannya, individu harus menyadari dan memahami sejauh mana karakteristik yang terdapat pada individu tersebut [5]. Karakteristik tersebut dapat dilihat dengan mengetahui kelebihan dan dapat menerima kelemahan pada diri sendiri dengan tidak melibatkan orang lain dan memiliki kemauan yang besar untuk mengembangkan dirinya.

Berdasarkan pengertian yang dipaparkan dari teori para ahli, dengan ini dapat disimpulkan penerimaan diri adalah individu yang memiliki perilaku dan pandangan positif terhadap dirinya yang di mana individu tersebut dapat menerima kekurangan dan kelebihan serta memiliki usaha dan kemauan untuk berubah dan berkembang menjadi individu yang baik untuk dirinya maupun orang yang berada di lingkungan sekitarnya. Dari pembahasan kasus dan teori yang telah dipaparkan di atas, maka dari itu membuat peneliti tertarik untuk melakukan penelitian dengan judul "Penerimaan Diri pada Remaja Panti Asuhan Putri Aisyiyah Medan". Penelitian ini memiliki tujuan untuk melihat bagaimana gambaran penerimaan diri yang ada pada diri remaja putri Panti Asuhan Puteri Aisyiyah Medan.

\section{Metode Penelitian}

Penelitian ini menggunakan metode penelitian kualitatif yang di mana peneliti berinteraksi secara langsung pada subjek yang diteliti. Denzin dan Lincoln (dalam Anggito \& Setiawan, 2018) penelitian kualitatif merupakan sebuah penelitian yang di mana menggunakan peristiwa alamiah untuk meninjau fenomena permasalahan yang terjadi dan menggunakan berbagai metode yang ada [2]. Poerwandari (2013) data yang digunakan dalam penelitian kualitatif bersifat dalam penyajian mengenai suatu fenomena, yang terdiri dari riwayat wawancara, dokumentasi lapangan berupa gambar,rekaman suara atau video, dan lain sebagainya [8].

Menurut Sarantakos (dalam Poerwandari, 2013) dalam penelitian kualitatif berusaha merumuskan pandangan dasar interpretif dan fenomenologis. Beberapa pandangan dalam pendekatan kualitatif yang mendasar adalah diantaranya bahwa kenyataan sosial sebagai suatu hal yang bersifat subjektif diinterpretasi, tidak di luar kemampuan, tidak secara langsung mengikuti hukum awal di luar diri, melainkan menciptakan rangkaian makna dalam menjalani hidupnya, ilmu didasarkan pada pengetahuan sehari-hari, bersifat induktif, idiografis dan tidak bebas nilai, serta bertujuan untuk memahami kehidupan sosial.

Subjek pada penelitian ini merupakan remaja puteri yang tinggal di panti asuhan yang berusia antara dua belas sampai lima belas tahun dengan jumlah subjek lima orang. Selain itu, penelitian ini juga menggunakan informan berjumlah dua orang, yang merupakan ibu pengurus panti asuhan dan kakak pengasuh anak panti asuhan.

Prosedur pengambilan subjek menggunakan teknik pengumpulan data purposive sampling. Purposive sampling adalah suatu teknik pengambilan sampel dari sumber data dengan pertimbangan tertentu. Misalnya seseorang yang dianggap paling dekat atau mengetahui tentang apa yang diharapkan, atau mungkin sebagai penguasa sehingga akan mempermudah peneliti untuk menjelajahi objek atau keadaan yang diteliti (Sugiyono, 2016) [12]. 
Teknik pengambilan data dalam penelitian ini menggunakan wawancara dan observasi. Menurut Slamet (dalam Edi, 2016) wawancara adalah cara yang dipakai guna memperoleh informasi dari kegiatan interaksi sosial antara peneliti dengan hal yang diteliti [6]. Di mana dalam penelitian ini, wawancara dilakukan dengan para subjek dan informan.

Selanjutnya adalah dengan metode observasi. Patton (dalam Sugiyono, 2016) ada beberapa manfaat dari observasi yaitu diantaranya peneliti akan lebih mudah memahami situasi, pengalaman secara melalui langsung, dapat melihat hal-hal yang jarang diamati orang lain, hal-hal yang sedianya tidak akan terungkapkan oleh responden dalam wawancara, mendapatkan gambaran yang lebih komprehensif dan dapat merasakan suasana dari situasi yang diteliti tersebut [12]. Observasi dalam penelitian ini dilakukan di panti asuhan tempat para subjek tinggal.

\section{Hasil Dan Pembahasan}

\begin{tabular}{ccccc} 
Subjek & Usia & Jenis Kelamin & Suku/Agama & Lama bergabung di Panti Asuhan \\
\hline E & 13 tahun & Perempuan & Jawa/Islam & 7 tahun \\
\hline RA & 12 tahun & Perempuan & Jawa/Islam & 6 bulan \\
\hline AW & 12 tahun & Perempuan & Jawa/Islam & 7 tahun \\
\hline SN & 12 tahun & Perempuan & Jawa/Islam & 4 bulan \\
\hline BFK & 12 tahun & Perempuan & Minang/Islam & 6 bulan
\end{tabular}

Berdasarkan wawancara dan observasi yang dilakukan, subjek pertama telah tinggal di panti asuhan selama tujuh tahun. Subjek merupakan anak yatim yang ayahnya yang telah meninggal dan kondisi ekonomi keluarga yang lemah, sehingga ibu subjek memutuskan untuk mengirimkan subjek ke panti asuhan agar subjek bisa mendapatkan pendidikan yang baik. Subjek memiliki kakak yang juga berada di panti asuhan yang sama dengan subjek. Pada saat ini subjek berada di tingkat SMP kelas dua. Meskipun subjek awalnya menentang keputusan ibunya, akan tetapi subjek telah bisa menerima keputusan ibunya untuk tinggal di panti asuhan. Subjek pertama memiliki kesadaran diri dan saling menghargai, serta memiliki kesadaran diri untuk mengakui kesalahan. Subjek juga berpikir positif, dengan status anak panti asuhan tidak membuat subjek merasa hal tersebut adalah kekurangan diri.

Subjek dikenal memiliki pribadi yang ceria dan semangat belajar yang kuat untuk dapat menjadi orang yang berguna pada masa depan. Dan jika dihadapkan terhadap suatu masalah, biasannya dirinya menyelesaikan masalah tersebut dengan bijak dan tidak terlalu membesar-besarkan masalah tersebut.

Subjek kedua telah tinggal di panti asuhan selama enam bulan. Subjek masih memiliki orang tua lengkap, namun karena kondisi ekonomi keluarga yang lemah, subjek dimasukkan oleh orang tuanya di panti asuhan. Subjek merupakan anak kedua dari tiga bersaudara. Subjek memiliki satu kakak perempuan dan satu adik laki-laki. Subjek selalu berusaha untuk saling menghargai satu sama lain.

Meskipun dengan status anak panti asuhan tidak membuat subjek merasa hal tersebut adalah kekurangan diri dan subjek berusaha untuk tidak mau berpikir yang negatif dan sedih jika dikritik orang lain mengenai status atau apa yang dibuatnya. Dan dalam hal menjalankan kegiatan sehari-hari subjek memiliki semangat belajar yang besar untuk mencapai cita-citanya. 
Dan jika dihadapkan terhadap suatu masalah, subjek akan menyelesaikan masalah tersebut dengan cara bertanya kepada orang lain. Subjek juga memiliki motivasi ingin berubah diri menjadi lebih baik dari kesalahan yang dilakukannya.

Subjek ketiga telah tinggal di panti asuhan selama tujuh tahun. Orang tua subjek sudah bercerai, dan ayah subjek juga sudah meninggal setelah orang tuanya bercerai. Dikarenakan ekonomi keluarga subjek yang tidak mampu, maka ibunya memutuskan untuk memasukkannya ke panti asuhan agar bisa disekolahkan. Subjek awalnya mengira tinggal di panti asuhan bersama orangtuanya, akan tetapi setelah masuk panti asuhan, subjek baru mengetahui bahwa dirinya tinggal di panti asuhan seorang diri. Pada saat itu, subjek tidak bisa menerima hal tersebut, tetapi seiring berjalannya waktu, dirinya sudah bisa menerima dan senang berada di panti asuhan dan tidak pernah merasa statusnya sebagai anak panti adalah suatu kekurangan.

Subjek juga merasa dirinya sudah cukup mandiri dan diajarkan untuk mencintai diri sendiri apa adanya, juga diajarkan untuk selalu ingat kepada Tuhan oleh pengasuh panti. Dan dapat menerima diri ketika mengalami kegagalan atau mendapatkan kritikan dan tidak menilai dirinya tidak baik, serta tidak peduli dengan ejekan orang terhadap dirinya. Subjek mengerjakan tugasnya sesuai dengan aturan dari panti. Selain itu, juga memiliki tekad untuk mencapai cita-citanya dengan cara rajin belajar. Dan Memiliki motivasi untuk mengubah dirinya.

Subjek keempat telah tinggal di panti asuhan selama empat bulan. Dikarenakan ekonomi keluarga subjek yang tidak mencukupi, maka orang tuanya memutuskan untuk mengirimkan anaknya ke panti asuhan agar diberikan pendidikan yang baik. Saat ini subjek duduk di bangku SD kelas enam. Walaupun awalnya menentang keputusan orang tuanya, akan tetapi dirinya harus bisa menerima keputusan dari orang tuanya untuk saat ini. Subjek memiliki kesadaran diri untuk meminta maaf apabila melakukan kesalahan. Meskipun berada di panti asuhan, hal itu tidak membuat dirinya berkecil hati. Selain itu, subjek juga tidak pernah membenci dirinya sendiri ataupun keluarganya.

Memilki pribadi yang kuat membuatnya jarang merasa sedih jika menerima kritikan orang lain. Dalam menjalankan kegiatan sehari-hari subjek mengetahui tugas yang telah menjadi kewajiban sehari-hari, dan tidak merasa keberatan akan hal jika memiliki suatu masalah, dirinya akan menyelesaikan masalah tersebut dengan cara bertanya kepada orang lain. Subjek juga tidak keberatan untuk memperbaiki kekurangan yang ada dalam diri.

Subjek kelima telah menempati panti asuhan selama enam bulan. Subjek merupakan anak kedua dari lima bersaudara. Yang di mana anak pertama, ketiga dan keempat laki-laki dan yang kelima perempuan. Dikarenakan kondisi keuangan dalam keluarganya tidak mencukupi maka dirinya terpaksa dimasukkan tinggal di panti asuhan.

Subjek dibujuk untuk masuk ke panti asuhan oleh ibunya dengan harapan dengan adanya keluarga baru dan hidup menjadi lebih nyaman, serta dapat bersekolah. Subjek memiliki kesadaran diri untuk meminta maaf apabila melakukan kesalahan. Dengan status anak panti asuhan tidak membuat dirinya merasa hal tersebut adalah kekurangan dan tidak pernah membenci dirinya sendiri ataupun keluarganya.

Ketika mengalami suatu konflik dalam hidupnya, dirinya berusaha untuk tetap berpikir positif. Sehingga saat menghadapi kegagalan atau mendapatkan kritikan yang buruk dirinya tidak mudah putus asa maupun malu. Melainkan belajar dari kegagalan tersebut. Hal itu dapat muncul dikarenakan dukungan dan ajaran yang diberikan dari panti asuhan tersebut.

Pembahasan Penelitian

Kelima subjek masing-masing memiliki penerimaan diri dan kesadaran diri, serta motivasi diri yang beragam di dalam diri mereka sendiri. Maka dapat disimpulkan bahwa individu cukup mampu menerima diri mereka dan status mereka sebagai anak panti asuhan. 


\section{Kesimpulan}

Kelima subjek merupakan remaja puteri panti asuhan yang di mana adalah anak remaja. Dengan latar belakang keluarga yang sudah tidak lengkap ataupun yang masih lengkap tetapi tidak harmonis, dan rata-rata memiliki latar belakang kondisi ekonomi keluarga yang kurang mampu. Penerimaan diri pada kelima subjek berada pada taraf yang baik. Karena kelima subjek telah menerima status mereka sebagai anak panti asuhan. Hal ini karena mereka selalu bersyukur apa adanya, memiliki kesadaran diri akan kewajiban, berpikir positif, dapat menerima diri jika dikritik orang lain, mampu mengembangkan potensi diri dan serta mempunyai motivasi untuk mengubah diri.

\section{Saran}

a. Bagi Remaja Panti Asuhan

Bagi seorang remaja panti asuhan memang membutuhkan waktu dan proses untuk dapat menerima status sebagai anak panti asuhan, cobalah untuk memahami dan menerima diri sendiri pada apa yang sudah terjadi dan membangkitkan kembali semangat di dalam diri sendiri remaja Panti Asuhan Puteri Aisyiyah Medan.

b. Bagi masyarakat

Diharapkan penelitian ini dapat membuat masyarakat memiliki pemikiran yang lebih terbuka mengenai anak panti asuhan.

\section{Daftar Pustaka}

[1] Alvin Tamba, Panti Asuhan Perlu Ditinjau Berkala, Harian Nasional, http://www.harnas.co/2018/07/24/panti-asuhan-perlu-ditinjau-berkala, 25 Juli 2018.

[2] Anggito, A., \& Setiawan, J, Metodologi Penelitian Kualitatif. CV Jejak, 2018.

[3] Bernard, M. E, The Strength of Self-Acceptance, In Springer. https://doi.org/10.1007/978-1-46146806-6, 2013.

[4] Chaplin, J, Kamus Lengkap Psikologi (Penerjemah K. Kartono ). PT. Raja Grafindo Persada, 2011.

[5] Cronbach, L, Educational Psychology. Harcourt, Brace \& World, Inc, 1963.

[6] Edi, F. R. S, Teori Wawancara Psikodiagnostik. PT. Leutika Nouvalitera, 2016.

[7] Hurlock, E. Psikologi Perkembangan Suatu Pendekatan Sepanjang Rentang Kehidupan. Erlangga, 1996.

[8] Poerwandari, K. Pendekatan Kualitatif Untuk Penelitian Perilaku Manusia. LPSP3, 2013.

[9] Resty, G. T. "Pengaruh Penerimaan Diri Terhadap Harga Diri Remaja Di Panti Asuhan Yatim Putri Aisyayah Yogyakarta," Jurnal Bimbingan Konseling., vol. 5, no. 4, hal. 1-12, 2016.

[10] Sahlan, A. Mendidik Perspektif Psikologi. Deepublish, 2018.

[11] Santoso, S. Dasar-Dasar Pendidikan TK. Universitas Terbuka, 2005.

[12] Sugiyono. Metode Penelitian : Kuantitatif, Kualitatif, dan R\&B. Alfabeta, 2016.

[13] Suprajitno. Asuhan Keperawatan Keluarga : Aplikasi Dalam Praktik. EGC, 2004.

[14] Sutadipura, B. Kompetensi Guru dan Kesehatan Mental. Angkasa, 2012.

[15] Varia. Ratusan Ribu Anak Tinggal di Panti Asuhan. Koran Jakarta. http://www.koranjakarta.com/ratusan-ribu-anak-tinggal-di-panti-asuhan/, 27 Juli 2018. 